IRA-International Journal of Technology \& Engineering ISSN 2455-4480

Proceedings of the

International Conference on Science \& Engineering for Sustainable Development (2017)

Pg. no.193-201

Published by: Institute of Research Advances https://research-advances.org/index.php/IRAJTE

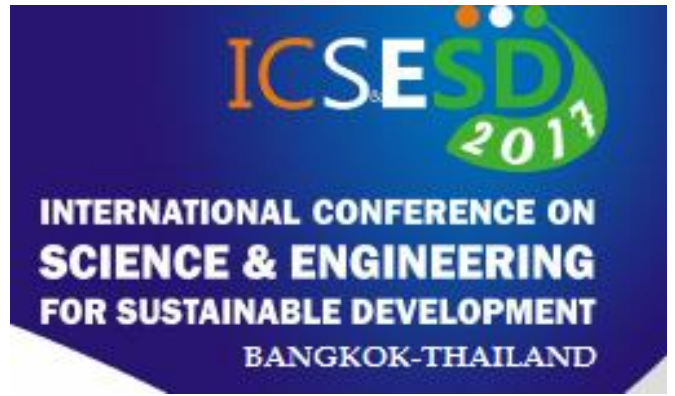

\title{
Evaluation of Cohesive Soil Mixed With Fly Ash and Reinforced With Nylon Fibre
}

\author{
Utkarsh. P. Gawande*1, Shubham. A. Kanhake ${ }^{2}$, Arjun. R. Lahane ${ }^{3}$, Prasanna. R. \\ Naghbhide ${ }^{4}$ \\ ${ }_{\mathbf{1 , 2 , 3 , 4}}$ Department of Civil Engineering, P.R.M.I.T. \& R, Badnera, India.
}

Type of Review: Originality Check \& Peer Review under the responsibility of the Scientific Committee of the Conference and The Institution of Engineers (India). DOI: http://dx.doi.org/10.21013/jte.ICSESD201719

\section{How to cite this paper:}

Gawande, U., Kanhake, S., Lahane, A., Naghbhide, P. (2017). Evaluation of Cohesive Soil Mixed With Fly Ash and Reinforced With Nylon Fibre. Proceedings of the International Conference on Science \& Engineering for Sustainable Development (2017), 193-201. doi: http://dx.doi.org/10.21013/jte.ICSESD201719

(C) International Conference on Science \& Engineering for Sustainable Development\& The Institution of Engineers (India).

\section{(cc) EY-NC}

This work is licensed under a Creative Commons Attribution-Non Commercial 4.0 International License subject to proper citation to the publication source of the work.

Disclaimer: The conference papers as published by the Institute of Research Advances (IRA) are the views and opinions of their respective authors and are not the views or opinions of the IRA. The IRA disclaims of any harm or loss caused due to the published content to any party. 


\section{ABSTRACT}

Black cotton soil is a expansive soil. And mostly found in Vidarbha region of Maharashtra, this soil is highly unstable and it should be stabilize for carry out construction work. Materials like fly ash, rise husk, nylon fiber are used to make soil stable. Addition of such material will increase the physical, chemical and engineering properties of soil. Some of the properties which are improved are CBR value, shear strength, liquidity index, plasticity index, unconfined compressive strength (UCS) and bearing capacity, etc. The main objective of this study was to evaluate the effect of fly ash in stabilization of Black cotton soil. Mainly UCS and other properties of soil were calculated. The tests were conducted on SoilFly Ash mixtures, by increasing the Fly Ash percentage in Black cotton soil like 25\%, 50\%, 75\%, and $100 \%$, and then the soil was tested on Soil-Fly Ash - Fibre mixture by adding the fiber in increasing order like $0.5 \%, 1 \%, 1.5 \%$. Results were obtained for mixed proportion of $75 \%$ soil and $25 \%$ fly ash which has unconfined compressive strength of $173 \mathrm{KN} / \mathrm{m}^{2}$. And by adding $1 \%$ of nylon fiber in same proportion of soil - fly ash the unconfined compressive strength increased to $243.12 \mathrm{KN} / \mathrm{m}^{2}$.

Increase in UCS value can help in reducing the thickness of earthen roads and pavements and increase the bearing capacity and shear strength of soil. With analysis of results it was found that the fly ash along with nylon fiber has good potential to be used as an additive for improving engineering properties of expansive soil.

Keywords: Expansive soil, Fly ash, Nylon fiber, engineering properties, Unconfined compressive strength

\section{Introduction}

\section{General}

Power is the key to prosperity and development of the nation. The necessity of providing electric power to the growing industrial as well as agricultural sectors has resulted in setting up of a large number of coal based thermal power stations in India. The projected values of gross electricity generation, the amount of coal required for electricity generation and the annual amount of fly ash produced are increase year by year. The total coal reserves in the country are about 201 billion tones. Out of this, 29.8 billion tones is coking coal, 24.7 billion tones is superior grade coal, 22.5 billion tones is intermediate grade coal and 124 billion tones is inferior grade coal. Thus, around seventy three present of non-coking coal reserve of the country is of the inferior quality.

The ash content of the coal used at the thermal plants in India ranges from $25 \%$ to $45 \%$. However, coal with an ash content of around $40 \%$ is predominantly used in India for thermal power generation. Since high grade coal which generates low ash is reserved for metallurgical industries, railways, etc., the thermal power plants have to use high ash; low grade coal. At present the ash generated in different thermal power plants in the country is around 123 million tone ash per year. The ash generation is projected to increase at least to 159 million tons per year by 2017. The projected huge fly ash generated could cause economic and management problems. Thus, it is very essential to find new avenues for utilization, which would result in mass consumption of fly ash generated.

Most of the thermal plants in India use the wet disposal system and dump the slurred fly ash into ash ponds. The existing thermal power plants had occupied 80,000 acres precious land for disposal of fly ash on year 2000. The requirement of land for disposal of fly ash slurry would increase with addition of more thermal plants. About $2 \%$ of capital cost of thermal power plant goes towards fly ash disposal systemize, approximately Rs. 20 crores in a $210 \mathrm{MW}$ plant. In addition, huge expenditure is done on operation and 
maintenance of ash slurry discharge and storage system. The dry collection systems would help in the commercialization and increased utilization of fly ash for different applications.

\section{Theoretical Background}

Fly ash in general

The materials collected from the burning of coal at thermal power plants are referred to power plant ash. These are produced in two forms: bottom ash and fly ash. Bottom ash is the slag which builds up on the heat absorbing surfaces of the furnace, and which subsequently falls through the furnace bottom to the ash hopper below.

Fly ash is the finely divided residue that results from the combustion of ground or powdered coal and is transported from the combustion chamber by exhaust gases. The quality of fly ash produced is dependent on different factors as the degree of pulverization of coal, design of furnace, changes in coal supply, changes in boiler load and hence the firing conditions. The huge amount of fly ash generated, is not only causing environmental problem, but also creating problems associated with its disposal, utilization, and threat to the public health.

\section{Literature Review}

Fly ash particles are predominately silt sized and grey in color. ASTM recognizes two classes of fly ash. Generally, class $\mathrm{F}$ fly ash is produced by burning bituminous or anthracite coal. Class $\mathrm{C}$ fly ash is produced by burning sub bituminous coal or ignites. Class $\mathrm{F}$ fly ash is the most common. It has pozzolonic properties but is not appreciably self cementing. Although not common, the production of class $\mathrm{C}$ fly ash has increased substantially in recent years. Class $\mathrm{C}$ fly ash is self cementing due to presence of lime or other chemical compounds.

Gatti and Tripicano (1981) carried out mineralogical analysis by means of X-ray diffractometer. The identified crystalline phases were mullite $\left(\mathrm{AL}_{6} \mathrm{Si}_{2} \mathrm{O}_{3}\right)$ about $25 \%$, and quartz $\left(\mathrm{SiO}_{2}\right)$ about $3 \%$. The presence of mullite was due to aluminous clay minerals contained in the coal.

The geotechnical characteristics of fly ash, fly ash soil mixtures were studied by different investigators to evaluate their suitability as structural fill / back fill and embankment fill material.

Raymond (1961) investigated the suitability of agrecroft and bold hopper fly ashes, from U.K for use as an embankment fill material. The geotechnical investigations carried out included compaction tests, unconsolidated undrained triaxial shear tests, permeability and California bearing ratio tests.

Maher et al. (1993) conductedlaboratory studies to find the feasibility of lime sludge amended fly ash for utilization as an engineered fill material. It was observed that the mixes compacted well and possessed relatively high compressive strength. The mixtures had low permeability and were successfully utilized as landfill cap and as a liner material.

Singh en at. (1996) studied the effects of different proportions mix proportions of lime and fly ash on compaction, California bearing ratio, Atterberg limits and unconfined compression properties of local soil of Varanasi to evaluate the suitability of fly ash-soil-lime as a base and sub base material for the roads.

\section{Fiber reinforced soil}

Earth reinforcement is proven effective and reliable technique for increasing the strength and stability of soil. Reinforced earth technique is one of the physical methods of soil improvement, the concept of which 
was introduced by Vidal of France in 1969. Vidal proposed the concept of soil reinforcing using oriented arrays of reinforcement such as metal, strips and bars. Reinforcement may vary in either form (strips, sheets, grids, bars or fibers), texture (smooth or rough) or relative stiffness (high such as steel or low such as fabric and fibers). Mc Gown et al (1978) pointed out the distinction between high modulus and low modulus reinforcement and classified the reinforcement into Major categories. (a) Ideally extensible inclusions (metals strips and bars) and (b) ideally extensible inclusion (natural and synthetic fiber, plants root and polymeric fabrics).

The effect of fiber inclusion on the permeability characteristics was studied using falling head method. The soil permeability increased with an increased in the fiber content. It was concluded that the main advantage of fiber inclusion in the cemented soil would be the improvement in the ductility of the material.

\section{Experimental Setup}

First we took the raw soil, and calculated all the geotechnical properties of soil, and just to increase the properties of soil, we added fly ash to the soil and performed the tests on soil and fly ash mixtures. Unconfined compression test (UCS) carried on soil-fly ash mixtures and the results obtained were showing the increase in strength of the soil. Then again the same soil fly ash mixture was added with the nylon fiber, hence to increase the shear strength, and bearing capacity of soil. The UCS was carried over the soil-fly ash-fiber sample and the results have the increased value of UCS.

1. Properties

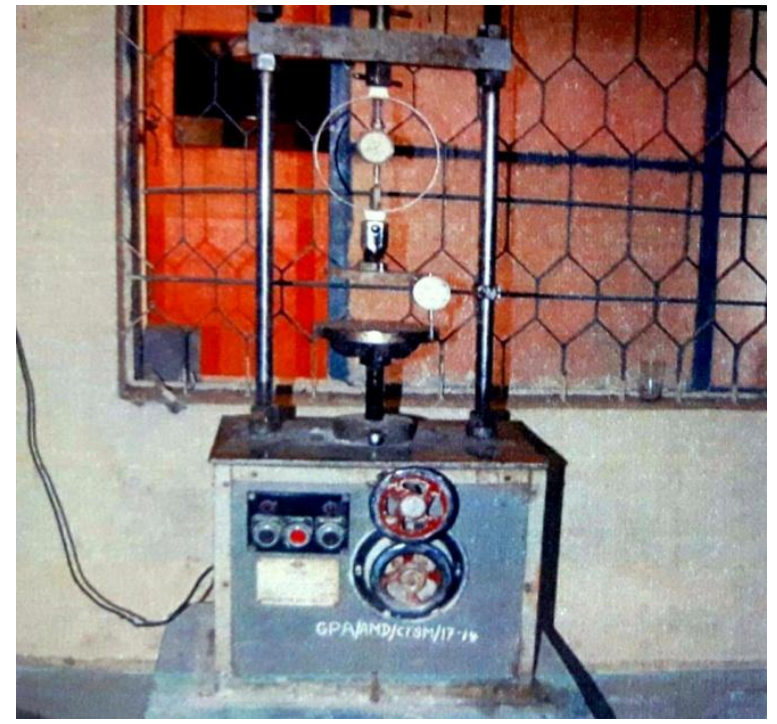

Unconfined compressive strength apparatus

The available black cotton soil is used in soil-fly ash mixture. The physical properties of soil used for the study are as follows -

Table No. 1

\begin{tabular}{|c|c|c|}
\hline $\begin{array}{c}\text { Sr. } \\
\text { no. }\end{array}$ & Property of soil & Value \\
\hline 1 & Liquid limit WL & $66.40 \%$ \\
\hline 2 & Plastic limit WP & $30.56 \%$ \\
\hline 3 & Plasticity index & $35.84 \%$ \\
\hline 4 & Specific Gravity & 2.265 \\
\hline 5 & $\begin{array}{c}\text { Maximum dry density } \\
\text { MDD }\end{array}$ & $1.53 \mathrm{gm} / \mathrm{cc}$ \\
\hline
\end{tabular}




\begin{tabular}{|c|c|c|}
\hline 6 & $\begin{array}{c}\text { Optimum moisture } \\
\text { content OMC }\end{array}$ & $17 \%$ \\
\hline 7 & $\begin{array}{c}\text { Unconfined } \\
\text { compression strength } \\
(\mathrm{q})\end{array}$ & $0.155 \mathrm{Mpa}$ \\
\hline 8 & $\begin{array}{c}\text { Classification of soil } \\
\text { as per IS1898-1974 }\end{array}$ & $\begin{array}{c}\text { CH (Inorganic } \\
\text { clay of high } \\
\text { plasticity) }\end{array}$ \\
\hline
\end{tabular}

Fly ash samples were collected from Koradi Thermal Power Station, Koradi. A large quantity of fly ash was collected in beginning of the study and stored properly in containers to ensure uniformity in characteristics of fly ash used throughout the study. The physical properties of fly ash are summarized in table below.

Table No. 2

\begin{tabular}{|l|l|l|}
\hline Sr.no. & \multicolumn{1}{|c|}{$\begin{array}{c}\text { Description of } \\
\text { properties }\end{array}$} & \multicolumn{1}{|c|}{ Value } \\
\hline 1 & Specific Gravity & 2.0 \\
\hline 2 & Liquid limit (\%) & $28 \%$ \\
\hline 3 & Plastic limit (\%) & Non plastic \\
\hline 4 & $\begin{array}{l}\text { Maximum dry density } \\
\left(\mathrm{KN} / \mathrm{m}^{3}\right)\end{array}$ & 13.24 \\
\hline 5 & $\begin{array}{l}\text { Optimum moisture } \\
\text { content }\end{array}$ & $24 \%$ \\
\hline 6 & Color & Grey \\
\hline 7 & Gravel & Nil \\
\hline 8 & Sand & $25 \%$ \\
\hline
\end{tabular}

Chemical composition of Koradi Fly Ash is given in the table below -

Table No. 3

\begin{tabular}{|c|c|c|}
\hline $\begin{array}{l}\text { Name of } \\
\text { the chemical }\end{array}$ & Symbol & $\begin{array}{l}\text { Range by } \% \\
\text { of weight }\end{array}$ \\
\hline $\begin{array}{l}\text { Surica } \\
\text { Alumina } \\
\text { Ferric Oxide } \\
\text { Titanium dioxide } \\
\text { Manganese Oxide } \\
\text { Calcium Oxide } \\
\text { Magnesium Oxide } \\
\text { Phosphorous } \\
\text { Sulphur Trioxide } \\
\text { Potassium Oxide } \\
\text { Sodium Oxide } \\
\text { Loss on ignition }\end{array}$ & $\begin{array}{l}\mathrm{SiO}_{2} \\
\mathrm{Al}_{2} \mathrm{O}_{4} \\
\mathrm{Fe}_{2} \mathrm{O}_{3} \\
\mathrm{TiO}_{2} \\
\mathrm{MnO} \\
\mathrm{CaO} \\
\mathrm{MgO} \\
\mathrm{P} \\
\mathrm{SO}_{3} \\
\mathrm{~K}_{2} \mathrm{O} \\
\mathrm{Na}_{2} \mathrm{O} \\
\mathrm{Lol}\end{array}$ & $\begin{array}{l}61 \text { to } 6.4 .29 \\
21.60 \text { to } 27.0 \\
3.09 \text { to } 3.86 \\
1.25 \text { to } 1.69 \\
\text { Up to } 0.05 \\
1.02 \text { to } 3.39 \\
0.5 \text { to } 1.58 \\
0.02 \text { to } 0.14 \\
\text { Up to } 0.07 \\
0.08 \text { to } 1.83 \\
0.26 \text { to } 0.48 \\
0.20 \text { to } 0.85\end{array}$ \\
\hline
\end{tabular}

\section{Results}

The maximum dry density (MDD) and the optimum moisture content (OMC) of all soil fly ash mixtures were determined by standard proctor tests. The compaction curves of different soil fly ash mixtures are summarized in fig. The MDD, OMC and other compaction characteristics of all soil fly ash are summarized in table below. 
Table No. 4

\begin{tabular}{|c|c|c|}
\hline $\begin{array}{c}\text { Mix } \\
\text { proportion } \\
\text { Soil : Fly } \\
\text { Ash }\end{array}$ & $\begin{array}{c}\text { Maximum } \\
\text { dry density } \\
\text { (gm/ml) }\end{array}$ & $\begin{array}{c}\text { Optimum } \\
\text { moisture } \\
\text { content }(\%)\end{array}$ \\
\hline $00: 100$ & 1.42 & 25 \\
\hline $25: 75$ & 1.43 & 23 \\
\hline $50: 50$ & 1.52 & 20 \\
\hline $75: 25$ & 1.47 & 20 \\
\hline $100: 00$ & 1.55 & 18 \\
\hline
\end{tabular}

Graph No. 1

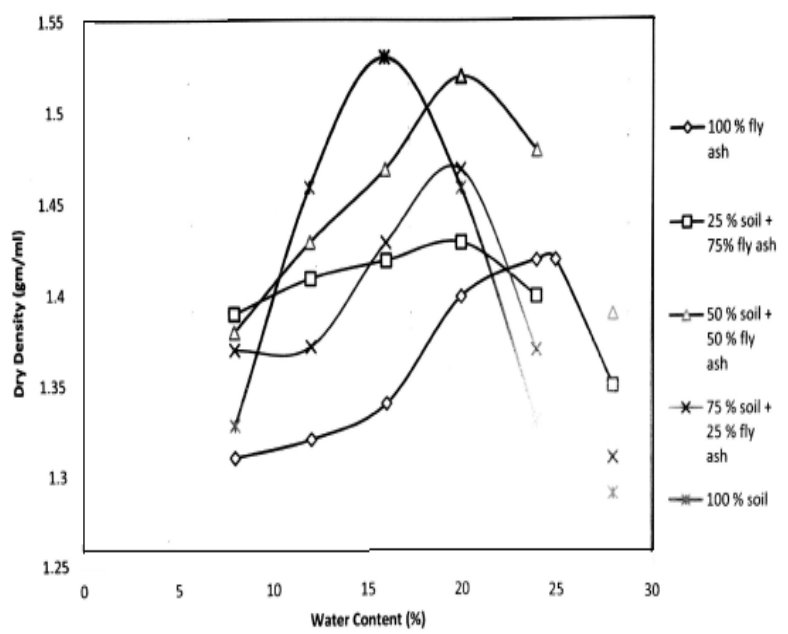

Compaction Curves for soil-Fly ash mixtures

Unconfined Compression Tests

Unconfined compression tests were carried out on specimen of size $38 \mathrm{~mm}$ X $76 \mathrm{~mm}$ for all soil Fly Ash mixtures. These samples were dynamically compacted at their respective calculated MDD and OMC as shown in above table. Minimum three samples were tested for each soil-Fly Ash mixtures specimens were tested at a deformation rate of $1.20 \mathrm{~mm} / \mathrm{min}$ and loading of specimen were continued till residual characteristics were obtained. The average unconfined compressive strength (UCS) and strain at failure $\left(€^{f}\right)$ of soil Fly Ash sample are summarized in table below

Table No. 5

\begin{tabular}{|c|c|c|}
\hline $\begin{array}{c}\text { Mix } \\
\text { proportion } \\
\text { Soil : Fly Ash }\end{array}$ & $\begin{array}{c}\text { Unconfined } \\
\text { compressive } \\
\text { Strength (UCS) } \\
(\text { KN/m²) }\end{array}$ & $\begin{array}{c}\text { Strain at } \\
\text { failure } \\
\boldsymbol{€}^{\mathrm{f}}(\%)\end{array}$ \\
\hline $00: 100$ & - & - \\
\hline
\end{tabular}




\begin{tabular}{|c|c|c|}
\hline $25: 75$ & 45.9 & $2.5-3.1$ \\
\hline $50: 50$ & 120 & $106 .-11.4$ \\
\hline $75: 25$ & 173 & $6.98-7.79$ \\
\hline $100: 00$ & 155 & $8.999-9.77$ \\
\hline
\end{tabular}

Graph No. 2

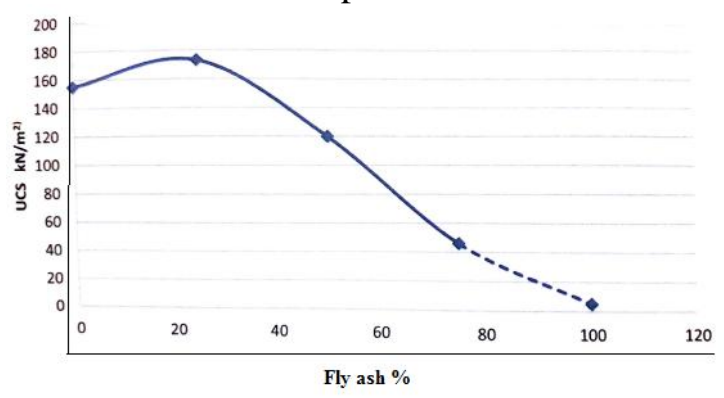

Variation of unconfined compressive strength with fly ash content for soil-fly ash mixtures

Graph No. 3

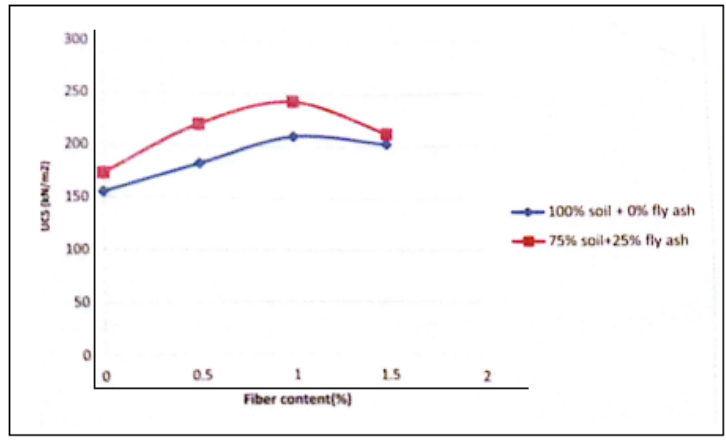

Variation of Unconfined compressive strength (UCS) of Unreinforced and fiber reinforced soil - fly ash mixtures (Fiber length $10 \mathrm{~mm}$ )

Unconfined compression test

Cylindrical specimen of size $37 \mathrm{~mm}$ X $87 \mathrm{~mm}$ were prepared by compacting samples in the three layers at maximum dry unit weight (MDD) and optimum moisture content (OMC) determined in standard proctor tests carried on respective soil-fly ash-fiber mixture. A total of 81 samples were prepared for fiber contents of $0.50 \%, 1.00 \%$, and $1.50 \%$ by dry weight with fiber length $=10 \mathrm{~mm}$. A minimum three specimens was tested for each combination of variables.

The average unconfined compressive strength (UCS) of unreinforced and fiber summarized in table below. 
Table No.6

\begin{tabular}{|c|c|c|}
\hline $\begin{array}{c}\text { Mix proportion } \\
\text { Soil : Fly ash }\end{array}$ & $\begin{array}{c}\text { Fiber content } \\
(\boldsymbol{\%})\end{array}$ & $\begin{array}{c}\text { UCS } \\
\left(\mathbf{K N} / \mathbf{m}^{2}\right)\end{array}$ \\
\hline $100 \%: 00 \%$ & 0.00 & 155 \\
\hline $100 \%: 00 \%$ & 0.50 & 183.2 \\
\hline $100 \%: 00 \%$ & 1.00 & 210.1 \\
\hline $100 \%: 00 \%$ & 1.50 & 203 \\
\hline
\end{tabular}

Soilfy Ash-Fiber Mixtures

The laboratory tests were carried out to study the geotechnical properties of then soil-fly ash mixtures reinforced with fiber. The soil and fly ash were, mixed in proportion of 100: 00, 75:25, and by dry weight, fibers varying from $0.50 \%, 1 \%, 1.5 \%$ by dry weight were added to each of these mixtures. The tests include compaction tests and the unconfined compression tests.

Standard proctor test compaction tests were carried out as per Indian standards specification for different combination of soil-fly ash-fiber. Samples were prepared and tested for fiber contents of $0.50 \%, 1.00 \%$, and $1.50 \%$ by dry weight with fiber length $=10 \mathrm{~mm}$.

Table No. 7

\begin{tabular}{|c|c|c|}
\hline $75 \%: 25 \%$ & 0.00 & 173 \\
\hline $75 \%: 25 \%$ & 0.50 & 221.08 \\
\hline $75 \%: 25 \%$ & 1.00 & 243.12 \\
\hline $75 \%: 25 \%$ & 1.50 & 213.03 \\
\hline
\end{tabular}

\section{Conclusion}

Based on the data accumulated from above research, following conclusions have been made the addition of fly ash to soil caused significant reduction in MDD and increase in OMC. The density of soil reduced by $5.16 \%, 1.93 \%$ and $7.74 \%$ when replaced with $25 \%, 50 \%$, and $75 \%$ fly ash by weight , respectively. The OMC of soil increased respectively when replaced with $25 \%, 50 \%$, and $75 \%$ fly ash by weight. The variation of MDD with fly ash content is nonlinear whereas the variation of OMC with fly ash content is nearly linear for all soil -fly ash mixtures. The unconfined compressive strength of soil -fly ash mixtures increases with increase in fly ash content it ranges from $0.5 \%$ to $25 \%$. Also, residual strength and strain energy absorption capacity the soil-fly ash mixtures increase with increase in fly ash content.

For all the fiber reinforced soil-fly ash mixtures tested, the peak strength increases with the fiber content. Thus in present analysis, the UCS has been defined as the stress corresponds to the peak stress condition or at $15 \%$ axial strain.

By comparing the UCS of soil -fly ash specimens, it is seen that, in unreinforced condition, fly ash has a lower UCS than soil and soil-fly ash specimens. However, the inclusion of fibers improves the UCS of soil and soil-fly ash specimens significantly than that I n fly ash.

The conclusion of study on a randomly oriented fiber reinforced soil-fly ash mixtures is that, maximum performance was achieved with $10 \mathrm{~mm}$ fibers in optimum dosage of $1.00 \%$ by dry weight of soil-fly ash mixtures. 


\section{References}

[1] AL Wahab, R.M. and EL- Kedrah, M.A. (2000). Using fiber to reduce tension and shrink/swell in compacted clay. Geoenvironment 2007, 791-805.

[2] Phani Kumar S.R. and Sharma R.S. (2004). - Effect of fly ash on engineering properties of expansive soils. I J. Geotech. Geoenviron. Eng.,130(7),764-

[3] Cokca, E. 2001, Use of class C fly ash for the stabilization of an expansive soil. "J. Geotech. Geoenviron. Eng", 127.7. (568-573.)

[4] Kaniraj S R, Havanagi V.G Geo technical characteristics of fly-ash soil mixtures. Geotechnical Engineering journal, 1999, 30 (2) 129-147.

[5] Kumar, V. (1996). Fly ash utilization: A mission mode approach. Ash ponds and ash disposal systems, Narosa Publishing House, New Delhi, India.

\section{Indian Standard}

1. IS 2720 (part 3, section 2) 1964- Specific gravity by density bottle.

2. IS 2720 (part 5) 1970- Liquid limit and plastic limit.

3. IS 2720 (part 11) 1977- Differential free swell index.

4. IS 2720 (part 7) 1980/ (part 8) 1983 Compaction characteristics of soil MDD and OMC by standard proctor test.

5. IS 2720 (part 16) 1979-UCS

6. IS $1898-1970$

1. A book, "Egg. Properties of soils, Tata McGraw Hill, New Delhi, 1978. By Gulhati S.K.

2. A book "Transportation Engineering". By N.L Arora. 